DOI 10.31558/2617-0248.2019.4.3

УДК $321.01 ; 342.2$

\title{
УНІТАРИЗМ ЯК ПОЛІТИЧНИЙ ТА ПРАВОВИЙ ФЕНОМЕН: ВІТЧИЗНЯНИЙ ТА ЗАРУБІЖНИЙ ДОСВІД
}

ORCID ID: https://orcid.org/0000-0002-0239-4539

Батанов О. В., д. ю. н., професор, провідний науковий співробітник відділу конституційного права та місцевого самоврядування Інституту держави і права ім. В. М. Корецького НАН України

У статті розкриваються сутнісні та змістовні характеристики унітаризму як феномену сучасного конституційного права. Показаний синергетичний зв'язок між принципами унітарності державної території та фундаментальними інститутами політико-правового та державно-управлінського життя сучасних унітарних держав. Доводиться, що унітарний устрій $\epsilon$ не лише одним із важливих компонентів процесу досягнення завдань, цілей та функцій більшості сучасних держав, а й іманентною ознакою та стратегічним елементом механізму реалізації їх суверенних прав.

Сучасний етап конституційного будівництва в Україні характеризується інтенсивним пошуком принципово нових рішень на шляху докорінної перебудови всіх аспектів держави та суспільства. Однією з нагальних і складних проблем, що виникли після проголошення незалежності української держави, $\epsilon$ питання вдосконалення територіальної організації влади та територіального устрою України. Адже територіальна система є одним із найважливіших інститутів державного устрою України. Цей інститут характеризує правові якості та властивості такого основного компонента держави, як ї̈ територія. Територіальна структура - це організація території держави. Територія $\epsilon$ необхідною умовою розвитку всього державного життя, утворюючи поряд з категоріями «народ» і «влада» тріаду елементів, що утворюють державу.

Складність, важливість та відносно широке використання унітарності як форми державного устрою викликає жвавий і постійно зростаючий науковий інтерес до неї у всьому світі. Унікальна здатність унітаризму враховувати специфічні особливості конкретного стану дозволяє йому проявляти себе в кожному випадку по-новому. Ось чому важливо проаналізувати взаємний вплив унітарної теорії та практики, дослідити та врахувати особливості національного унітаризму.

Проблема унітаризму та унітарної форми територіального устрою держави та статусу ії складових $\epsilon$ однією з найменш вивчених увітчизняному конституційному праві. Сучасні представники науки конституційного права, як правило, обмежуються розглядом окремих питань території, зокрема, особливостей територіальної організації державної влади та місцевого самоврядування, проблем державного суверенітету, територіальної цілісності та недоторканність тощо. Значною мірою недостатнє вивчення проблеми в сучасній Україні спричиняє труднощі успільному розумінні таких явищ, як унітаризм, федералізм та федералізація, регіоналізм та регіоналізація, децентралізація та деконцентрація тощо. Слід зазначити, що у сучасній літературі з питань державної території, територіальної організації державної влади та інших питань статусу території складний, багатовимірний характер унітаризму як конституційної категорії не завжди враховується.

У контексті дослідження значна увага приділяється також проблемам становлення та розвитку конституційної моделі організації державної влади в Україні з точки зору принципів субсидіарності та децентралізації.

Ключові слова: унітаризм, територія, держава, державний устрій, адміністративно-територіальний устрій, державний кордон, функції території.

\section{Batanov O.V. Unitarism as a Political and Legal Phenomenon: Domestic and Foreign Experience}

The article reveals the essential and substantial characteristics of unitarism as a phenomenon of modern constitutional law. It is shown that a synergistic relationship between the principles of the national territory is unitary and fundamental political and legal institutions, and public-administrative life of the modern unitary states. It is proved that a unitary device is not only an important component of the process of achieving goals, objectives and functions of the majority of modern states, but also a sign of an immanent and strategic element of the implementation mechanism of their sovereign rights.

The current stage of constitutional construction in Ukraine is characterized by an intense search for fundamentally new solutions on the path of radical restructuring of all aspects of state and society. One of the pressing and complex problems that have arisen since the independence of the Ukrainian state is the issue of improving the territorial organization of power and the territorial structure of Ukraine. After all, the territorial system is one of the most important institutions of the state system of Ukraine. This institute characterizes the legal qualities and properties of such a basic component of the state as its territory. The territorial structure is 
the organization of the territory of the state. Territory is a prerequisite for the development of all state life, forming, along with the categories of «people» and "power», a triad of elements that form the state.

The complexity, importance, and relatively widespread use of unitarity as a form of government is causing a lively and ever-growing scientific interest in it throughout the world. The unique ability of unitarism to take into account the specific features of a particular state allows it to manifest itself in each case in a new way. That is why it is important to analyze the mutual influence of unitary theory and practice, to explore and take into account the peculiarities of national unitarism.

The problem of unitarism and the unitary form of the territorial structure of the state and the status of its constituents is one of the least studied in domestic constitutional law. Modern representatives of the science of constitutional law, as a rule, are limited to consideration of individual issues of the territory, in particular, the peculiarities of the territorial organization of state power and local self-government, problems of state sovereignty, territorial integrity and inviolability, etc. To a large extent, the lack of study of the problem in contemporary Ukraine causes difficulties in the common understanding of phenomena such as unitarism, federalism and federalization, regionalism and regionalization, decentralization and deconcentration, etc. It should be noted that in the contemporary literature on the issues of the state territory, territorial organization of state power and other issues of the status of the territory, the complex, multidimensional nature of unitarism as a constitutional category is not always taken into account.

In the context of the study, considerable attention is also given to the problems of establishing and developing a constitutional model of public authority organization in Ukraine in terms of the principles of subsidiarity and decentralization.

Key words: unitarism, territory, state, state structure, state border, administrative-territorial structure, the function of the territory.

Сучасний етап конституційного будівництва в Україні характеризується інтенсивним пошуком принципово нових рішень на шляху корінної перебудови усіх сторін життя держави і суспільства. Однією з актуальних та надскладних проблем, які постали після набуття незалежності української держави є питання вдосконалення територіальної організації влади та територіального устрою України. Адже територіальний устрій є одним 3 найважливіших інститутів державного ладу. Цей інститут характеризує юридичні якості та властивості такого основного складового елементу держави як її територія. Територіальний устрій $є$ організацією території держави.

Будь-яка держава має свою територію, яка визначає просторові межі розповсюдження їі влади. Масштаби і структура території істотно впливають на організацію публічної влади, іiі форми, функції та повноваження. 3 метою найкращого здійснення цієї влади ії̈ організація у більшості випадків прив'язується до структурних частин території даної держави. У ряді випадків це можуть бути тільки звичайні адміністративно-територіальні одиниці, у інших особливі автономні територіальні утворення, у третіх - більш або менш самостійні держави або подібні ним утворення.

Сьогодні для сучасної України проблематика територіальної організації влади, адміністративнотериторіального устрою та територіального устрою, захисту територіальної цілісності має особливе значення. Відповідно до Конституції України за формою територіального устрою наша держава $є$ унітарною. Перед Українським народом та українською державою постали низка складних внутрішніх та зовнішніх загроз та викликів, насамперед, пов'язаних з такими фундаментальними конституційними цінностями, як суверенітет, незалежність, свобода, демократія, територіальна цілісність тощо. Адже триває анексія Автономної Республіки Крим та збройна інтервенція Російської Федерації проти України, під впливом та за підтримкою агресора діють терористичні утворення в Луганській та Донецькій областях, перманентно активізуються сепаратистські тенденції в різних регіонах України, штучно інспіруються федералістські сценарії ії конституційного розвитку, мовні та конфесійні конфлікти та протиріччя тощо.

Ці та інші проблеми об'єктивно пов'язані з проблематикою територіального устрою України та його принципів, серед яких унікальне та системоформуюче значення має унітаризм. Унітаризм - це конституційноправовий феномен, поняття, сутність, зміст, цілі та перспективи розвитку якого є предметом наукового інтересу протягом багатьох століть. Однак у вітчизняній і зарубіжній юридичній літературі триває пошук парадигми унітаризму відповідно до сучасних умов зміненого світопорядку. У той же час різноманіття думок щодо ключових загальнотеоретичних питань свідчить про актуалізацію теорії і практики будівництва унітарних держав, а значна теоретична база унітаризму постійно вимагає доповнення з огляду на те, що практика будівництва унітарних відносин динамічно розширюється, так як принципи унітаризму знаходять широке застосування не тільки в територіальній організації публічної влади унітарних держав, а й в процесах інституціоналізації та функціонування соціальної, економічної, фінансової та інших систем унітарних держав світу. Унітаризм постійно розвивається, розкривається з нових сторін і вимагає ретельного доктринального конституційно-правового осмислення.

Окремі аспекти теорії та практики сучасного унітаризму, адміністративно-територіального устрою та процесу у своїх працях досліджували М. О. Баймуратов, Ю. І. Ганущак, Б. П. Гдичинський, Р. В. Губань, О. П. Іщенко, В. М. Кампо, О. Л. Копиленко, В. В. Кравченко, І. О. Кресіна, В. С. Куйбіда, О. Г. Кучабський, І. Й. Магновський, В. І. Нудельман, Х. В. Приходько, С. О. Телешун, А. Ф. Ткачук, В. М. Шаповал, Л. Т. Шевчук та iн. Проте комплексне дослідження унітаризму як конституційного феномену з врахуванням тенденцій його функціонування та розвитку не проводилося. 
Враховуючи вказане, сучасний український унітаризм потребує додаткового дослідження, насамперед, в аспекті його сутності, змісту, принципів, зміцнення в контексті реформи адміністративно-територіального устрою, реформування місцевого самоврядування та децентралізації публічної влади, тенденцій і перспектив розвитку конституційної доктрини та практики унітаризму в умовах нового світового порядку, а також викликів, які постали перед Україною в результаті анексії Автономної Республіки Крим та збройної агресії з боку Росії тощо.

3 огляду на сказане, мета цієї статті полягає у тому, щоб окреслити деякі концептуальні політичні та правові аспекти у розумінні унітаризму у сучасному світі.

Термін «унітарна держава» походить з латинського слова unus, unitas, що означає «один», «єдність». Унітарна держава, таким чином, складається не з державних утворень, а з адміністративно-територіальних одиниць, правовий статус яких визначається центральною владою. Унітарний характер держави означає, що територія у межах існуючих державних кордонів $є$ цілісною і недоторканною, що складові частини цієї території перебувають у нерозривному взаємозв'язку, відзначаються внутрішньою єдністю і не мають ознак державності, як це властиво складовим частинам, скажімо, федеративної держави.

Концептуально значущими є й інші характеристики унітарної держави. Наприклад, деякими дослідниками акцентується увага не тільки на ії так званих «матеріальних» характеристиках, а й підкреслюється сприяння забезпеченню унітаризму факторів нематеріального змісту. Саме такий підхід демонструє визначення унітарної держави, представленої як простого єдиного державного утворення, що складається з юридично рівних адміністративно-територіальних одиниць, які підпорядковані центральним органам влади і не мають ознак державного суверенітету, а більшість населення в такій державі має унітарну правосвідомість. «Унітарна правосвідомість» належить до групи ознак, які не обмежуються лише формою державної атрибутики та технологічною характеристикою унітарної держави. Унітарна правосвідомість - це більше, ніж обов'язкова ознака державності та унітарної спроможності. Ця характеристика передує та виступає основою унітаризму. Це своєрідна національна традиція територіальної організації та форма ії̈ історичної та сучасної конституціоналізації.

В контексті універсалізації методологічних підходів до унітарних характеристик сучасної держави особливої уваги заслуговує системний підхід. У західній доктрині права поняття «унітарна система» визначається як система політичної організації, при якій усі або більшість владних повноважень зосереджені на рівні центрального уряду, на відміну від федеральної системи. В умовах унітарної системи центральний уряд, як правило, делегує повноваження територіальним одиницям і дозволяє останнім реалізовувати прийняті політичні рішення.

Аналізуючи генезис унітарної форми державного устрою, потрібно виходити з того, що унітаризм замінив партикуляризм і феодальну роздробленість, відіграв свою прогресивну роль. Він не залежав від національноетнічної чи расової структури населення, а був затребуваний єдиним режимом, відносною простотою в здійсненні державної влади. Унітарна держава в даний час $\epsilon$ найбільш розповсюдженою у світі формою державного устрою. Понад 85 \% країн світу обрали унітарну форму свого територіального устрою. Незважаючи на те, що це різні за своїми територіальними параметрами, етнонаціональним складом, географічним розташуванням, економічним та соціально-культурним розвитком, політичними та правовими традиціями держави, унітарним державам притаманна комплексна система ознак.

Серед них визначаються такі: територія держави поділена на адміністративно-територіальні одиниці, які не наділені державним суверенітетом; єдина структура державного апарату, компетенція якого поширюється на всю територію держави; єдине громадянство; єдина система законодавства, осьовим центром якої є єдина державна конституція; єдина судова система; єдина система органів конституційного контролю; одноканальна система оподаткування; у міжнародних відносинах виступає єдиним цілим; є лише одна загальнонаціональна конституція, норми якої застосовуються на території всієї країни без будь-яких обмежень, а також існує тільки загальнонаціональне громадянство.

В аспекті забезпечення державно-управлінської організації кожна з них має суттєві особливості. Наприклад, Велика Британія, децентралізує владу на практиці, але не в конституційних принципах. Це одна з небагатьох країн, яка обрала деволюцію як форму децентралізації та територіальної організації. Інші країни наділяють різним ступенем автономності територіальні одиниці. У Франції- класичному прикладі децентралізованої адміністративної системи, деякі члени місцевої влади призначаються центральним урядом, тоді як інші обираються.

Для унітарної держави характерна єдина система вищих органів (парламент, глава держави, уряд). Юрисдикція цих органів розповсюджується на всю територію країни, яка поділяється на адміністративнотериторіальні одиниці, які не мають політичної самостійності. В цих одиницях (департаменти, області, округа, райони, міста тощо) звичайно утворюються власні представницькі та виконавчі органи, які функціонують у відповідності з загальнонаціональним законодавством та зобов'язані застосовувати законодавчі та інші нормативні акти, які приймаються центральними органами державної влади.

Територія унітарної держави завжди має свою внутрішню організацію або так званий адміністративнотериторіальний устрій (виключенням є лише так звані мікродержави), суть якого зводиться до поділу єдиної території держави на складові частини. Територія унітарної держави являє собою не що інше, як велику політичну та соціально-економічну суперсистему, що у визначених державним кордоном межах поєднує ключові функціональні підсистеми життєдіяльності суспільства («управління», «виробництво», «обслуговування», «розселення») та певною мірою локалізує їх у межах конкретних адміністративно-територіальних одиниць існуючого адміністративно-територіального поділу. Лише у тих випадках, коли локалізація зазначених підсистем на території відповідає існуючому адміністративно-територіальному устрою (відповідно, і існуючій системі управління) адміністративно-територіальний устрій можна розглядати, як оптимальний. 
Адміністративно-територіальний устрій унітарної держави традиційно грунтується на певних принципах, тобто керівних засадах, що визначають сутність і зміст цього інституту державного ладу i, як правило, закріплюються в конституції та законах. Загальноприйняте, що адміністративно-територіальний устрій унітарної держави грунтується на засадах єдності та цілісності державної території; поєднання централізації і децентралізації у здійсненні публічної влади; збалансованості і соціально-економічного розвитку регіонів, 3 урахуванням їх історичних, економічних, екологічних, географічних i демографічних особливостей, етнічних i культурних традицій.

Принцип єдності та цілісності території означає, що складові частини державної території - адміністративнотериторіальні одиниці - знаходяться у нерозривному взаємозв'язку, визначаються внутрішньою єдністю в межах державного кордону.

Принцип централізації та децентралізації в здійсненні державної влади проявляється в тому, що за центральними (загальнодержавними) органами держави закріплюється право забезпечення внутрішніх $\mathrm{i}$ зовнішніх загальнонаціональних інтересів, регулювання всіх сфер суспільного і державного ладу - політичної, економічної, соціальної, культурної (духовної), екологічної та зовнішньополітичної, а обов'язок захисту суверенітету і територіальної цілісності визначається як найважливіша функція держави. За місцевими органами державної влади традиційно закріплюється право вирішувати питання регіонального і місцевого значення, сприяючи реалізації загальнодержавних програм.

Аналізуючи різні національні унітарні системи з точки зори їх внутрішньої організації, можна констатувати, що одними з ключових факторів застосування того чи іншого типу такої системи $є$ баланс та рівновага централізованого та децентралізованого підходів (принципів) функціонування публічної влади. Тому, принцип централізації органічно пов'язаний з принципом децентралізації, що знаходить своє вираження у визнанні та гарантуванні місцевого самоврядування. Муніципалізація конституційного життя та конституційного права, передусім маючи вихід на локальний рівень, торкається усіх процесів трансформації та модифікації публічної влади в умовах демократизації держави та суспільства. Ці процеси не можуть не відбиватись і на ході реалізації форми державного устрою, зокрема його модифікаціях у стані утвердження та розвитку. Акценти розставляються на основних складових: традиційному для унітарної держави адміністративно-територіальному устрою та «муніципально-територіальному устрою», який є територіальною основою місцевого самоврядування та ключовим просторово-організаційним ресурсом оптимізації локальної мережі публічних послуг.

Доцільність застосування такої дворівневої моделі державного устрою є результатом посилення тенденції децентралізації в країнах Європейського Союзу i, як наслідок, формування нового етапу подальшої конституціоналізації та законодавчої імплементації принципу децентралізації на національному рівні. Цей процес зумовлює законодавче забезпечення, насамперед, територіальної та адміністративної основ системи державної влади та системи місцевого самоврядування, в умовах яких вирішення питань місцевого значення $є$ прерогативою місцевого самоврядування. Якщо під централізацією розуміють тип публічного управління, що характеризується зосередженням (тобто концентрацією) функцій соціального і державного управління в центральних владних структурах (органах, установах, відомствах тощо); вертикальними зв'язками, за яких верхні рівні влади наділені широкими повноваженнями у прийняття рішень, а їх директиви (накази, постанови, рішення тощо) є обов'язковими для нижчих рівнів. То децентралізацією визначається послідовний процес передачі (тобто деконцентрації) із центру на місця частини функцій і повноважень центральних органів держави.

Як слушно зауважують вітчизняні експерти, держава, якщо вона демократична, не може обійтися без децентралізації системи публічного управління територіями, зокрема виконавчої влади, що, в свою чергу, має дві основі форми, відомі світовій практиці урядування та самоврядування - адміністративну та демократичну. Децентралізація демократична передбачає перенесення (деволюцію) частини державної виконавчої влади на рівень населення відповідних адміністративно-територіальних одиниць (територіальних громад, общин, комун, муніципалітетів, територіальних колективів) i тих органів, які воно обирає (органів місцевого самоврядування). Децентралізація адміністративна передбачає створення на місцях спеціальних урядових органів (місцевих державних адміністрацій, префектур, урядових комісаріатів тощо), які становлять так звану урядову або виконавчу вертикаль.

Враховуючи досвід децентралізованих європейських країн, варто відзначити, що констатація обраного курсу децентралізації як однієї з умов модернізації та оптимізації територіальної, адміністративної та інших основ надання публічних послуг населенню потребує подальшої конкретизації виду/типу/моделі децентралізації на конституційному та законодавчому рівнях. У зв'язку з цим цілком слушними є зауваження зарубіжних експертів щодо доцільності широкої класифікації децентралізації (яка за своєю сутністю, змістом і формами не зводиться до реформи місцевого самоврядування), критеріями якої виступають, насамперед, вибір i політичний курс держави; форма держави; рівень політико-правової культури громадян; рівень відповідальності публічного менеджменту; готовність суспільства до постійної взаємодії з владою тощо. Такий диференційований підхід дозволяє більш точно визначитись з факторним складом процесу децентралізації, а також надати найбільш реальні прогнози щодо іiі результатів, ризиків і перспектив. Зокрема, виходячи з положень про те, що децентралізація - це, насамперед, перехід влади та відповідальності за здійснення публічних функцій від центру до підпорядкованих квазінезалежних організацій і приватного сектору, зарубіжні дослідники акцентують увагу на, по суті, галузевому підході до типів децентралізації, таких як: політична, адміністративна, фіскальна, ринкова, які, в свою чергу, мають свої особливості та види.

Обгрунтування цих видів децентралізації зумовлено відповідними видами компетенції публічної влади різних рівнів - державного, регіонального та муніципального, а також видами публічних послуг та механізмами їх 
надання. Виходячи з того, що однією з основних функцій як державного устрою, так i адміністративнотериторіального устрою є забезпечення територіальної (просторової) та адміністративної (управлінської) основ надання публічних послуг населенню держави, правова визначеність компонент і механізмів децентралізації, ii процесуально-правова урегульованість є одним із факторів ефективності реалізації цього принципу.

Принцип децентралізації є комплексним і багатоаспектним за своїм змістом і обсягом. Зарубіжний досвід успішно проведених реформ адміністративно-територіального устрою на основі поєднання принципів централізації та децентралізації свідчить про те, що неоднозначне сприйняття сутності, змісту і обсягу цих принципів призводить до виникнення проблем їх імплементації на національному рівні. Так, не зважаючи на те, що сучасний процес децентралізації в країнах євразійського та європейського континентів триває з другої половини ХХ століття, ми можемо спостерігати нові етапи і нові форми децентралізації в регіональній і муніципальній політиці, пропонованої Радою Свропи та Європейським Союзом, в основу яких покладено принцип субсидіарності.

Традиційно принцип субсидіарності трактується як основа місцевого самоврядування в децентралізованих державах. Однак, не слід обмежувати його дію та вплив лише інститутом місцевого самоврядування. Оскільки останній виступає функціональною основою територіальної та адміністративної організації держави. Свідченням цього є досвід адміністративно-територіальних і муніципальних реформ країн Європейського Союзу, які будучи його асоційованими членами або країнами-кандидатами проходили шлях децентралізації. Прикладом є Литва, Латвія, Естонія, а також Чехія, Польща, Угорщина, асоційовані члени Європейського Союзу Грузія, Україна. Крім цього новітній досвід набувають країни з розвинутими децентралізованими системами Франція та Норвегія. У Франції з 2014 р. здійснюється реформа адміністративно-територіального устрою відповідно до принципів субсидіарності, раціональності, оптимальності та обгрунтованості, на яких акцентується увага міжнародними організаціями в своїх рекомендаціях, зокрема Радою Європи, Конгресом місцевих та регіональних влад, організацією «Об’єднані міста та місцеві влади». Норвегія з 2015 р. продовжує процес удосконалення територіальної організації шляхом чергової хвилі об'єднання територіальних колективів, пропонуючи заохочувальні фінансові механізми за для цього. При чому мотивуючим фактором, за словами Міністра місцевого управління та модернізації Норвегії є, по суті, скорочення видатків та оптимізація мережі надання публічних послуг в умовах великих розмірів території та низької густоти (щільності) населення.

У сучасному значенні принцип субсидіарності є європейським стандартом визначення компетенції на рівнях територіальної організації публічної влади та управління, делегування повноважень між цими рівнями щодо надання публічних, зокрема державних і громадських послуг населенню та означає адекватний, фактичний та ефективний розподіл владних повноважень між органами державного, регіонального та місцевого рівнів публічної влади з метою наближення надання державних та громадських послуг безпосередньо до їхніх споживачів.

Слід відзначити, що принцип централізації та децентралізації територіального устрою знаходить своє логічне продовження і в інших принципах організації та діяльності органів державної влади та органів місцевого самоврядування, розмежуванні їх функцій та повноважень.

Важливими є принципи адміністративно-територіального устрою, які визначають сутність і зміст регіональної політики унітарної держави, визнають і гарантують права територіальних колективів тощо. Важливе значення має й принцип системності територіального устрою, який передбачає, що територіальний устрій має певну систему, що складається з взаємопов'язаних адміністративно-територіальних одиниць, які перебувають між собою структурними і функціональними зв'язками.

Принципами територіального устрою та адміністративно-територіального поділу, який є важливими засадою демократичного державного ладу європейських країн $є$ повсюдність; розробка оптимального науково зваженого понятійно-категоріального інструментарію, який би виключав будь-яку двозначність тлумачень; компактність, тобто адміністративно-територіальні одиниці повинні бути компактними, без анклавів та віддалених відступів; спадкоємність - основні характеристики адміністративно-територіального поділу мають враховувати історичні, національно-культурні, соціально-економічні особливості території, по можливості, повинні зберігати наявні межі інфраструктур та комунікацій; гнучкість та адаптивність- адміністративно-територіальний устрій повинен порівняно легко пристосовуватися до територіальних змін у суспільстві - змін в соціальних та управлінських технологіях, економіці, розселенні, споживанні; наявність оптимальної «критичної маси»- адміністративнотериторіальні одиниці повинні мати достатню фінансово-економічну базу для забезпечення населення відповідними послугами тощо.

Виходячи з гуманітарної спрямованості функціональних характеристик сучасного адміністративнотериторіального устрою варто підкреслити його людиноцентристську (ліберальну) концепцію, яка є і тенденцією, i закономірністю еволюційного розвитку людства. Освоєння території людиною є природним процесом, а пошук гармонії їх співіснування складає первинну ціннісну основу і такого явища як адміністративно-територіальний устрій. У зв'язку з цим набуває особливої актуальності проблематика публічної обгрунтованості, зокрема економічної, соціальної доцільності запровадження тієї чи іншої моделі територіального устрою.

Соціально значущим результатом теоретичного та прикладного дослідження принципів публічної обгрунтованості є висновки про те, що шляхом публічної аргументації стає можливим уникнення конфлікту між індивідуальними прагненнями та публічними інтересами. Завдяки вдалому обгрунтуванню індивідуальні прагнення можуть стати як складовою, так і основою публічних інтересів. Тобто, в умовах вибору, реформування та утвердження певної моделі територіального та адміністративно-територіального устрою є важливим підготовка громадськості та усебічне інформування суспільства щодо питань доцільності та раціональності прийняття того чи іншого публічного рішення. 
Прикладом вдалого застосування методу публічного обгрунтування в сфері публічного управління виступає концепція деліберативної демократії, яка формується наприкінці XX століття. Аналізуючи трилогію «причина - публічна аргументація - незгода» як так звані ідеї делібералізації політичного діалогу, в основі якого теорія «колективного політичного вибору», іiї прихильники акцентують увагу на функціонуванні раціональної легіслатури, функціональній партисипативній демократії, а також громадському самоврядуванні. Ці чинники виступають важливими інструментами створення сталої моделі територіальної та адміністративної організації держави.

У контексті предмету даного публікації є доволі цікавим та повчальним досвід таких складних унітарних держав - членів Європейського Союзу, які мають у своєму складі автономії. Іноді такі країни називають унітарними державами з автономними включеннями. Це - Корсика у Франції; Північна Ірландія (Ольстер) у Великій Британії; автономні області в Італії; Азорські острови та Мадейра у Португалії; Гренландія та Фарерські острови у Данії; автономні співтовариства в Іспанії; Аландські острови у Фінляндії.

Враховуючи, що до групи складних за своєю політико-територіальною організацією унітарних держав відноситься й Україна, у складі якої є Автономна Республіка Крим, яка, попри їі анексію та окупацію з боку Російської Федерації, згідно ст. 134 Конституції України залишається невід'ємною складовою частиною України, досвід країн Європейського Союзу в аспекті організації та функціонування автономій є дуже важливим та пізнавальним.

Найдавнішими своєрідними автономіями в Європі, що існували задовго до нової ери, були грецькі містаполіси. Автономні утворення у Стародавньому Римі мали дещо інші форми: до них належали окремі колонії, муніципії - громади провінційних міст, які з давніх часів перебували у складі Римської держави. За муніципіями зберігалося право внутрішнього самоврядування - свої міські магістрати, автономні суди. Поряд із цими видами громад, що мали різні ступені автономності, в Римі існували також так звані вільні міста, які мали јus ехіtu (право виходу), тобто широку автономію. Історичне значення запровадження автономії у республіканському Римі полягає в тому, що таким чином багатьом народам було забезпечено виживання, певний розвиток продуктивних сил, $\mathrm{i}$ прилучення до більш високих форм цивілізації.

Період феодалізму в Західній Європі характеризується тим, що на їі території сформувалося кілька великих державних об'єднань з автономіями різних форм. Найпотужнішим серед них було ранньофеодальне королівство Німеччина, яке упродовж тривалого часу залишалося децентралізованим державним утворенням, до складу якого входили десятки, а в окремі періоди і сотні феодальних володінь. Такого роду автономні утворення відігравали важливу роль у державотворчому процесі та задоволенні інтересів окремих груп населення.

Автономією як специфічною формою територіальної організації публічного управління є територія, якій держава для врахування національних, історичних, економічних, географічних, релігійних та інших особливостей населення в окремих адміністративно-територіальних одиницях надає розширені права з питань місцевого значення або забезпечує політичні та духовно-культурні запити різних форм цих груп населення шляхом їх екстериторіальної самоорганізації.

Автономія відіграє значну роль в удосконаленні державного устрою у сучасних багатонаціональних унітарних і федеративних державах, зокрема у комплексному розв'язанні трьох головних проблем: децентралізації влади, регулюванні міжнаціональних відносин та захисті культурних цінностей народів, що проживають на території даної країни.

Наявність автономних утворень, безумовно, ускладнює політико-територіальну організацію цих держав, вносить у неї певну асиметрію. Але сама по собі наявність на території даної країни однієї, двох або навіть більше автономій ще не виводить iї за рамки унітарності та не перетворює iї у федерацію. Адже, автономність і суверенність - це якісно різні виміри самостійності політико-територіальних одиниць, суб'єктів. Загальна тенденція демократизації устрою держав у сучасному світі визначає загальну тенденцію зростання децентралізації територіального устрою різних країн, розширення автономії та місцевого самоврядування. Найбільш яскравою демонстрацією цих тенденцій децентралізованого та регіоналізованого унітаризму, або так званого «квазіфедералізму», є перетворення у сучасний період ряду унітарних держав у «держави автономій», уся або переважна частина території яких складається автономних одиниць. Їх нерідко взагалі називають регіоналістськими державами, які упевному сенсі займають проміжне місце між унітарними та федеративними державами, не виходячи у загальному та цілому за рамки унітаризму.

Попри зазначені тенденції, світовий досвід підтверджує те, що унітаризм $є$ перевірений часом та історично й політично обумовленим феноменом, найбільш стабільною та ефективною з точки зору організації публічної влади формою державного устрою. 